\title{
Estimation of Fecal Output and Particulate Passage Rate with a Pulse Dose of Ytterbium- labeled Forage
}

\author{
L.J. KRYSL, F.T. MCCOLLUM AND M.L. GALYEAN
}

\begin{abstract}
Twelve rumen-cannulated lambs (avg. wt. $40 \mathrm{~kg}$ ), fed long-stem alfalfa or prairie hay in a crossover design (two, 15-day periods) were used to compare estimates of fecal output from a pulse dose of ytterbium (Yb)-labeled forage and fecal collection bags. Estimates of fecal output (g/day) with Yb-labeled forages were not different $(P>.05)$ from total collection values for lambs fed either alfalfa or prairie hay. Fecal output from a pulse dose of $\mathrm{Yb}$ was $100 \pm 2 \%$ of total collection for lambs fed alfalfa and $103 \pm 3 \%$ for lambs fed prairie hay. Particulate passage from the rumen was faster $(P<.01)$ in lambs fed alfalfa $(\mathbf{7 . 0 \%} / \mathrm{hr})$ then in lambs fed prairie hay $(3.9 \% / h r)$. A pulse dose of Yb-labeled hay appears to prove reliable estimates of fecal output as well as passage rate estimates, but validation of techniques in free-grazing ruminants is needed.

Optimum animal production and forage utilization on rangelands requires measurements of forage intake and nutritive value. With grazing ruminants, however, monitoring these factors is dif-

Authors are graduate research assistant, respectively, Department of Animal and Range Sciences, Box 3-1, New Mexico State University, Las Cruces, NM 88003; assistant professor, Animal Science Department, Oklahoma State Univ., Stillwater, OK 74074; and associate professor, Department of Animal and Range Sciences, Box 3-I, New Mexico State University, Las Cruces, NM 88003.

The authors thank Drs. D.M. Hallford, J.L. Holechek and R.E. Estell for reviewing the manuscript.

This manuscript is Journal Article 1069 of the New Mexico Agr. Exp Sta., Las Cruces.

Manuscript accepted July 5, 1984.
\end{abstract}

ficult. Forage intake of grazing ruminants has generally been determined by estimates of fecal output coupled with measures of indigestibility. Total fecal collection has been used by a number of workers (Handl and Rittenhouse 1972, Lake et al. 1974, Cordova et al. 1978), but the technique is expensive and labor intensive, and it may alter normal grazing behavior (Brisson 1960, Corbett 1960 Cordova et al. 1978). Indirect estimates of fecal output with the fecal nitrogen index method (Arnold and Dudzinski 1963) and chromic oxide have also been reported. Although chromic oxide has been used extensively in range nutrition studies, variation in marker recovery, diurnal variation in marker excretion and analytical difficulties have been noted as problems with the technique (Raleigh et al. 1980).

Recently, rare earth elements have received attention as markers for determination of particulate passage rate (Ellis 1968, Hartnell and Satter 1979, Teeter et al. 1979, Ellis et al. 1982). Compartmental modeling techniques (Ellis et al. 1979) applied to fecal marker excretion curves from a pulse dose of rare earth markers can be used to determine fecal output as well as passage rate; however, limited data are available regarding the validity of fecal output estimates determined with this technique. The objective of this study was to compare fecal output estimates determined by total fecal collection and a pulse dose of ytterbium-labeled forage. 


\section{Experimental Procedure}

Twelve finewool $\times$ Suffolk wethers (avg. wt. $40 \mathrm{~kg}$ ) fitted with $2.54 \mathrm{~cm}$ interal diameter rumen cannulas were used in a crossover design with 2,15-day periods. Six lambs were fed alfalfa hay and 6 fed prairie hay ( $90 \%+$ bluestem, Andropogon spp.) in period 1, and forage treatments were reversed in period 2. Between periods, lambs were outside for 14 days and allowed to adapt to new diets. All lambs were housed in metabolism stalls and fitted with fecal collection bags on day 1 of each period. Long-stem hay was fed daily at 1200 hours in quantities sufficient for ad libitum consumption and water was provided free choice. No salt was provided.

Days 1-9 of each period served as an adaptation period to diets and metabolism stalls. On days 10 through 15 of each period, quantitative estimates of feed intake and fecal output were recorded for each lamb. Also on day 10 , each lamb was dosed via rumen cannula with a gelatin capsule containing ytterbium (Yb)labeled hay. Lambs fed alfalfa were dosed with $14.2 \mathrm{~g}$ of alfalfa hay dry matter containing $10.6 \mathrm{mg} \mathrm{Yb} / \mathrm{g}$ dry matter $(150.2 \mathrm{mg} \mathrm{Yb}$ in dose) and those fed prairie hay received a dose of $14.3 \mathrm{~g}$ prairie hay dry matter with $8.9 \mathrm{mg} \mathrm{Yb} / \mathrm{g}$ (127 mg Yb in dose). Hays were labeled (McCollum and Galyean 1982, Teeter et al. 1984) by soaking $50 \mathrm{~g}$ of coarsely chopped (2-5 cm particle length) hay (leaves and stems) with 1 liter of a solution containing $2.5 \mathrm{~g}$ of $\mathrm{YbCl}_{3} \bullet \mathrm{XH}_{2} \mathrm{O}$ for 24 hours. After soaking, excess fluid was poured off and remaining hay was washed with 1 liter of deionized water every hour for a 6-hour period and then dried at $50^{\circ} \mathrm{C}$ for 48 hours in a forced-draft oven. Rectal grab samples of feces were obtained from lambs at $0,4,8,12,16,20,24,28,32,36,48,54,60,72,84,96,108$ and 120 hours postdosing. Fecal samples were then stored frozen. On day 15 of each period, rumen fluid was drawn from each lamb, composited by treatment group, and used as an inoculum to determine in vitro organic matter disappearance with a 48 hour rumen fluid and 48 hour acid pepsin digestion (Tilley and Terry 1963).

Fecal samples were thawed, dried at $50^{\circ} \mathrm{C}$ and ground through a 2-mm screen in a Wiley mill. Dry matter and ash were determined by standard procedures (AOAC 1980). Fecal ash was solubilized with $25 \%(\mathrm{v} / \mathrm{v})$ hydrochloric acid and $\mathrm{Yb}$ content was determined by atomic absorption spectroscopy using an acetylene/nitrous oxide flame (McCollum and Galyean 1982). Potassium (2000 $\mu \mathrm{g} / \mathrm{ml}$ ) was included in standards and samples as an ionization buffer. Hay samples were ground through a $2-\mathrm{mm}$ screen and dry matter and ash content were determined as previously described. Kjeldahl nitrogen (AOAC 1980), neutral detergent fiber, acid detergent fiber and acid detergent lignin (Goering and Van Soest 1970) were also determined in hay samples.

Fecal Yb excretion curves were evaluated with one- and twocompartment models (Ellis et al. 1979) using the nonlinear regression option (Marquardt method) of the Statistical Analysis System (Helwig and Council 1979). The one-compartment model fit the data for all lambs; however, the two-compartment model only fit data from about half of the lambs. Therefore, only data from the one-compartment model are reported. The equation for the onecompartment model is as follows:

$\mathrm{Y}=\mathrm{k}_{\mathrm{o}} \bullet(\mathrm{t}-\mathrm{tau}) \cdot\left(\mathrm{k}_{1}\right)^{2} \cdot \mathrm{e}^{-\mathrm{k}_{1} 1^{(\mathrm{t}-\mathrm{tau})}}$

where

$Y=$ marker concentration in feces

$\mathbf{k}_{\mathbf{o}}=$ initial marker concentration in compartment

$k_{1} \cdot \quad$ time dependent rate constant

$t$. time postdosing

tau time from dose until first appearance of marker in feces.

Calculations from parameter estimates include

8 Flow, $\% / \mathrm{hr}=\left(\mathrm{k}_{1} \times .59635\right) \times 100$

Fecal output $/ \mathrm{hr}=\frac{\text { dose }}{\mathrm{k}_{\mathrm{o}}}$

Total mean retention time in the gastrointestinal tract, $\mathrm{hr}_{\mathrm{r}}=2 / \mathrm{k}_{1}$ + tau.

Passage rate data and the percentage difference between fecal output determined from $\mathrm{Yb}$ versus total collection were analyzed as a crossover design with a model which included effects for lamb, period and treatment (hay). Fecal output estimates (g/day) from $\mathrm{Yb}$ versus total collection within hays were compared with a paired t-test (Snedecor and Cochran 1967).

\section{Results and Discussion}

Chemical composition of the hays is shown in Table 1. As expected, crude protein content was considerably higher for alfalfa $(18.7 \%)$ than for prairie hay $(7.8 \%)$. Acid detergent fiber was lower and acid detergent lignin higher in alfalfa than prairie hay. Neutral detergent fiber was also higher for the prairie hay. Legumes typically contain less cell wall than grasses and more lignin (Van Soest 1982). In vitro organic matter disappearance was 17.7 percentage units higher for alfalfa than prairie hay.

Table 1. Chemical composition (dry matter basis) of alfalfa and prairie hays.

\begin{tabular}{lcc}
\hline \hline & Alfalfa Hay & Prairie Hay \\
\cline { 2 - 3 } & \multicolumn{3}{c}{$\%$} & \\
\cline { 2 - 3 } Dry matter & 92.2 & 92.9 \\
Ash & 10.8 & 11.0 \\
Crude protein & 18.7 & 7.8 \\
Neutral detergent fiber & 52.8 & 79.0 \\
Acid detergent fiber & 29.3 & 41.4 \\
Acid detergent lignin & 7.6 & 5.8 \\
In vitro organic matter & & \\
$\quad$ disappearance & 52.4 & 34.7 \\
\hline
\end{tabular}

Fecal output estimates from a pulse dose of $\mathrm{Yb}$-labeled hay averaged $100 \%$ of total collection values for alfalfa hay and $103 \%$ of total collection values for prairie hay (Table 2). Estimates of actual fecal output $(\mathrm{g} / \mathrm{d})$ did not differ $(P>.05)$ between Yb-labeled hay and total collection for either alfalfa or prairie hays. Moreover, the percentage difference (Yb estimate/total collection estimate) did not differ $(P>.10)$ between alfalfa and prairie hay. Thus, a pulse dose of $\mathrm{Yb}$ provided mean estimates of fecal output comparable to total fecal collection, and the accuracy of the fecal output estimate did not appear to be related to forage quality. Mader (1981), working with cattle grazing wheat pasture observed fecal output from a pulse dose of Yb-labeled forage to range from 94 to $105.5 \%$ of total collection values. Prigge et al. (1981) used 8 cows dosed once daily for 5 days with Yb-treated hay in gelatin capsules followed by twice daily fecal sampling for 7 days. Fecal output estimates with $\mathrm{Yb}$ did not differ from total collection values, and the authors concluded the $\mathrm{Yb}$ was as effective as $\mathrm{Cr}_{2} \mathrm{O}_{3}$ as a marker for estimation of fecal output.

Assumptions involved with a pulse dosing technique as used in the present study are that marker is potentially $100 \%$ recoverable and that marked particles mix and move at a constant rate (Ritten-

Table 2. Intake, fecal output estimates, particulate passage rate, first appearance of marker in feces and total mean retention time in lambs fed alfalfa and prairie hays.

\begin{tabular}{|c|c|c|c|}
\hline Item $^{1}$ & Alfalfa hay & Prairie hay & $\mathrm{SE}^{2}$ \\
\hline Dry matter intake, $g /$ day & $1007^{\mathrm{a}}$ & $767^{\mathrm{b}}$ & 60.1 \\
\hline \multicolumn{4}{|l|}{ Fecal output } \\
\hline Total collection & 426 & 420 & 26.5 \\
\hline Yb-labeled forage ${ }^{3}$ & 424 & 435 & 28.5 \\
\hline$\%$ difference & 100 & 103 & 2.0 \\
\hline $\mathbf{K}_{1}, \% /$ hour $^{4}$ & $7.0 \mathrm{a}$ & $3.9 \mathrm{~b}$ & 0.4 \\
\hline Tau, hours 5 & $12.1 \mathrm{c}$ & 14.6d & 0.8 \\
\hline TMRT $^{4}$ & $30.4 \mathrm{a}$ & $46.0 \mathrm{~b}$ & 1.5 \\
\hline
\end{tabular}

${ }_{1} K_{1}=$ rate of particulate passage from the rumen, Tau $=$ time to first appearance of marker in feces and TMRT = total mean retention time in the gastroinestinal tract. 2Standard error of treatment means based on 12 observations/treatment

${ }^{3}$ Means for $\mathrm{Yb}$ labeled forage vs. total collection within alfalfa and prairie hays do not differ $(P>.05)$.

${ }^{4}$ Row means with different letters differ $(P<.01)$

${ }^{4}$ Row means with different letters differ $(P<01)$.
sRow means with different letters differ $(P<10)$. 
house et al. 1982). Neither assumption can be tested in the present study; however, the fact that fecal output estimates from Yblabeled forage were not different from total collection estimates suggests that assumptions were most likely met.

If the pulse dosing technique provides reliable estimates of fecal output, an advantage of the technique is that estimates of particulate passage rate can be obtained from the same data. Passage rate estimates from the present study are shown in Table 2. Passage of particulates from the rumen $\left(\mathrm{k}_{1}\right)$ was faster $(P<.01)$ for alfalfa compared with prairie hay $(7.0 \mathrm{vs.} 3.9 \% / \mathrm{hr})$. Moreover, tau (time in hours to first appearance of marker in feces) and total mean retention time of marker in the gastrointestinal tract (TMRT) were less ( $P<.10$ and $P<.01$, respectively) for alfalfa than for prairie hay. Faster passage of particulates would be expected to alfalfa due to its greater digestibility (Table 1) and also to the higher dry matter intake (Table 2) of lambs fed alfalfa. In this study coarsely chopped hay was chosen as the substrate for $\mathrm{Yb}$ labeling in an attempt to simulate the particle size of masticated long-stem hay. The extent to which divergence from actually consumed particle size would have affected passage rate results is unknown. A more appropriate substrate for $\mathrm{Yb}$ labeling would be esophogeal masticate samples.

Results of this study suggest a pulse-dose of $\mathrm{Yb}$-labeled forage can provide reliable estimates of fecal output. However, the validity of such estimates under free grazing conditions needs further evaluation. Rittenhouse et al. (1982) reported correlations between total collection estimates and estimates based on rare earth markers in free grazing cows. Clearly, if only estimates of fecal output are desired, the use of fecal collection bags with grazing animals would be a much simpler approach than the use of a pulse dose of Yb-labeled forage. If, however, investigators want estimates of fecal output and particulate passage rate, a pulse docs technique could be of considerable value. Recently, McCollum (1983) investigated seasonal variation in intake, particulate passage rate and diet quality in cattle grazing blue grama (Bouteloua gracilis) rangelands and reported particulate passage rate, dietary neutral detergent fiber concentration and 4-hour in vitro organic matter disappearance were the best predictors of organic matter intake. Thus, for situations in which a critical examination of the digestive physiology of the grazing ruminant is needed, pulse dose techniques with Yb-labeled forage may provide a useful research tool.

\section{Literature Cited}

AOAC. 1980. Official Methods of Analysis (13th Ed.). Ass. of Off. Analytical Chem. Washington, D.C.

Arnold, G.W., and M.L. Dudzinski. 1963. The use of faecal nitrogen as an index for estimating the consumption of herbage by grazing animals. J. Agr. Sci. 61:33-43.
Brisson, G.J. 1960. Indicator methods for estimating amount of forage consumed by grazing animals. Proc. Int. Grassl. Cong. 8:435-438.

Corbett, J.L. 1960. Faecal-index techniques for estimating herbage consumption by grazing animals. Proc. Int. Grassl. Cong. 8:438-442.

Cordova, F.J., J.D. Wallace, and R.D. Pieper. 1978. Forage intake by grazing livestock: A review. J. Range Manage. 31:430-438.

Ellis, W.C. 1968. Dysprosium as an indigestible marker and its determination by radioactive analysis. J. Agr. Food Chem. 16:220.

Ellis, W.C., J.H Matis, and C. Lascano. 1979. Quantitating ruminal turnover. Fed. Proc. 38:2702-2706.

Fllis, W.C., C.L. Lascano, R. Teeter, and F.N. Owens. 1982. Solute and particulate flow markers. In: F.N. Owens (Ed.) Protein Requirements for Cattle: Symposium. Okla. State Univ. MP-109:37:56.

Goering, H.K., and P.J. Van Soest. 1970. Forage fiber and analysis (apparatus, reagents, procedures and some applications). USDA-ARS Handbook No. 379 .

Handl, W.P., and L.R. Rittenhouse. 1972. Herbage yield and intake of grazing steers. Proc. West. Sec. Amer. Soc. Anim. Sci. 23:197-200.

Hartnell, G.F., and L.D. Satter. 1979. Determination of rumen fill, retention time and rumen turnover rates of ingesta at different stages of lactation in dairy cows. J. Anim. Sci. 48:381-392.

Helwig, J.T., and K.A. Council. 1979. SAS User's Guide. SAS Institute, Inc., Gary, N.C.

Lake, R.P., D.C. Clanton, and J.F. Karn. 1974. Intake, digestibility and nitrogen utilization of steers consuming irrigated pasture as influenced by limited energy supplementation. J. Anim. Sci. 38:1291-1297.

Mader, T.L. 1981. Effects of feeding low-quality roughages on performance and wheat forage utilization of stocker cattle. Ph.D. Dissertation, Oklahoma State Univ., Stillwater.

McCollum, F.T. 1983. The influence of advancing season on nutritive quality, intake and rumen fermentation of cattle diets on blue gramma rangeland. Ph.D. Dissertation. New Mexico Univ., Las Cruces.

MeCollum, F.T., and M.L. Galyean. 1982. Effects of forage type and prelabelling treatment on $\mathrm{Yb}$ binding efficiency, $\mathrm{Yb}$ concentration and in vitro organic matter digestibility of esophageal masticate samples. Proc. West. Sec. Amer. Soc. Anim. Sci. 33:33-36.

Prigge, E.C., G.A. Varga, J.L. Vioini, and R.L. Reid. 1981. Comparison of ytterbium chloride and chromium sesquioxide as fecal indicators. $J$. Anim. Sci. 53:1629-1633.

Raleigh, R.J., R.J. Kartchner, and L.R. Rittenhouse. 1980. Chromic oxide in range nutrition studies. Agr. Exp. Sta. Bull. 641. Oregon State Univ., Corvallis

Rittenhouse, L.R., D.E. Johnson, and M.M. Borman. 1982. Comparison of fecal excretion and intake estimates obtained from external markers and total fecal collection. Proc. West. Sec. Amer. Soc. Anim. Sci. 33:284-286.

Snedecor, G.W., and W.G. Cochran. 1967. Statistical Methods (6th Ed.). Iowa State Univ. Press, Ames, lowa.

Teeter, R.G., F.N. Owens, and G.W. Horn. 1979. Ytterbium as a ruminal marker. J. Anim. Sci. 49(Suppl. 1):412.

Teeter, R.G., F.N. Owners, and T.L. Mader. 1984. Ytterbium chloride as a marker for particulate matter in the rumen. J. Anim. Sci. 58:465-473.

Tilley, J.M.A., and R.A. Terry. 1963. A two stage technique for the in vitro digestion of forage crops. J. Brit. Grassl. Soc. 18: 104.

Van Soest, P.J. 1982. Nutritional Ecology of the Ruminant. O.\& B. Books, Inc., Corvallis, Oregon. 